\title{
Brainstem biopsies in adults: Review of 80 consecutive cases
}

\author{
Marcos Dellaretti ${ }^{1,2}$, Baltazar Leão Reis ${ }^{1}$, Gustavo Touzet' \\ Nicolas Reyns², François Dubois², Sebastião Gusmão ${ }^{3}$, Serge Blond² \\ Department of Neurosurgery, Hospital da Santa Casa de Belo Horizonte, Belo Horizonte, MG, Brazil \\ Department of Neurosurgery, Hospital Roger Salengro. Lille, France
}

\section{ABSTRACT}

Objective: To retrospectively review the morbidity and mortality rates associated with stereotactic brainstem lesion biopsy, the success rate and the impact on treatment. Material and methods: Eighty consecutive stereotactic biopsies and literature review were performed to analyze clinical, radiographic and histopathological data. Results: Stereotactic biopsy of brainstem lesions conducted to the diagnosis in $96.3 \%$. One death (1.3\% of cases) occurred and $10 \%$ morbidity was associated with the procedure. Pathology showed that $65 \%$ of the adult brainstem intrinsic lesions were gliomas, $11.3 \%$ were metastasis, $8.7 \%$ were lymphomas and the remaining tumoral lesions were ganglioglioma, ependymoma and craniopharyngeoma. Non-tumoral lesions were the diagnosis in 11 cases. Conclusion: Empiric treatment of adult brainstem lesions is not prudent, because a wide spectrum of pathologies occur in this location. Stereotactic biopsy is a safe and effective method for determining the diagnostic of these lesions.

\section{KEY WORDS}

Brainstem biopsy. Stereotactic biopsy.

\section{RESUMO}

Biópsia estereotáxica das lesões do tronco cerebral. Estudo de 80 casos consecutivos Objetivo: Analisar retrospectivamente as taxas de morbidade e mortalidade associadas ao procedimento de biópsia estereotáxica das lesões do tronco encefálico, assim como sua taxa de sucesso e impacto no tratamento. Material e métodos: Foram analisados retrospectivamente 80 casos consecutivos de biópsia estereotáxica de lesões do tronco encefálico e confrontados seus dados clínicos, imagiológicos e histopatológicos com dados da literatura atual. Resultados: A biópsia estereotáxica das lesões do tronco encefálico obteve diagnóstico em $96,3 \%$ dos casos. A taxa de mortalidade foi de 1,3\% e de morbidade de $10 \%$. Estudo histopatológico evidenciou que $65 \%$ das lesões intrínsecas do tronco encefálico do adulto eram gliomas, $11,3 \%$ eram metástases, $8,7 \%$, linfomas, e o restante das lesões tumorais eram gangliogliomas, ependimomas e craniofaringeomas. Foram diagnosticadas lesões não tumorais em 11 casos. Conclusão: Tratamento empírico das lesões do tronco encefálico do adulto não é prudente em virtude do amplo espectro de patologias que podem acometer esta região. Concluímos que a biópsia estereotáxica é método seguro e efetivo para determinar o diagnóstico de tais lesões.

\section{PALAVRAS-CHAVE}

Biópsia do tronco encefálico. Biópsia estereotáxica.

\section{Introduction}

Stereotactic brainstem biopsy was first reported in 1978 and it was initially widely used to obtain samples from brainstem lesions. ${ }^{4}$ Proponents of this procedure claimed that stereotactic biopsies were safe, presented high diagnostic yield and low morbidity and mortality rates. ${ }^{16,17,18}$ It has also been reported that brainstem tumors are better managed once a definitive tissue diagnosis has been established. ${ }^{7}$ More recently, however, with the improved resolution of magnetic resonance imaging (MRI), it has been recommended that intrinsic brainstem lesions should not be subjected to routine biopsy and that the procedures should be reserved for patients with an atypical lesion in this region. ${ }^{12}$

1 Department of Neurosurgery, Santa Casa Hospital. Belo Horizonte, MG, Brazil.

2 Department of Neurosurgery, Hospital Roger Salengro. Lille, France.

3 Department of Neurosurgery, Hospital das Clínicas da Universidade Federal de Minas Gerais, Brazil. 
The aim of this study is to retrospectively review the morbidity and mortality rates, success rate and the impact on treatment associated with the surgical procedure. glioma. Survival was estimated by the Kaplan-Meier method and its 95\% confidence intervals. Comparison of Kaplan-Meier curves was performed using the logrank statistic. Parameters were deemed to be statistically significant at a value of $\mathrm{p}<0.05$.

\section{Material and methods}

Between February, 1984 and August, 2007, 80 brainstem biopsies were performed at the Roger Salengro Hospital in Lille, France, in adult patients with intrinsic brainstem lesions not amenable to excision. Of these, 32 were women and 48 men, with a mean age of 41 years (ranging from 18 to 75 years). Patients were followed from 4 days to 229 months after biopsy (mean 31.2 months).

The mean duration of symptoms was 4.8 months. Symptoms consisted of walking disturbance in 42 patients, visual impairment in 41 , dysphagia in 21 , signs of intracranial hypertension in 16, facial paresis in 26 and hemiparesis in eight.

The lesions were centered in the midbrain in 16 patients, the pons in 15 patients, the medulla in 1 patient, the midbrain-pons in 21 patients, the ponsmedulla in 20 patients and the midbrain-pons-medulla in 7 patients.

\section{Surgical technique}

After induction of general anesthesia 58 patients underwent a stereotactic biopsy procedure with a Talairach frame and 22 underwent robotic brainstem biopsy (NeuroMate systems). In all patients MRI was used to target the biopsy site within the lesion. Serial sampling was performed at every $10 \mathrm{~mm}$ through the trajectory by using a side-cutting Sedan needle. The center of the lesion was targeted and, when enhancement was identified, this region was also targeted. A transfrontal approach was used in 65 patients and a transcerebellar approach in 15 patients. All biopsy specimens were formalin-fixed and analyzed after staining with $\mathrm{H}$ \& E, Masson trichrome and immunostains.

\section{Data and statistical analysis}

Data analysis was performed using Epi info 6.02 and Medicalc 9.3.0.9. Univariate analysis of the following variables was performed with regard to the morbidity rate and the success of the procedure: approach (transfrontal vs transcerebellar) and technique used (Talairach vs Robotic).

Survival time was measured from the time of biopsy to the date of last follow-up or death of the patients with

\section{Results}

A precise histological diagnosis were established in $77(96.3 \%)$ patients, and diagnosis were confirmed by the patient clinical course. Twenty-five (32.5\%) were determined as low-grade gliomas, including 3 astrocytoma grade II, 10 oligoastrocytoma grade II, 8 oligodendroglioma grade II, 3 pylocitic astrocytoma and 1 pleomorphic xanthoastrocytoma. High-grade glioma was the diagnosis in 25 cases: 6 glioblastoma multiforme, 7 anaplastic astrocytoma, 9 oligoastrocytoma grade III and 3 oligodendroglioma grade III.

By the time of the last follow-up visit in August 2007, 27 patients $(56.2 \%)$ diagnosed with glioma had died. The mean overall survival of this population, measured from the date of biopsy, was 40 months for the low-grade glioma and 9 months for the high-grade glioma $(p<0.05)$. Figure 1 shows the comparison of Kaplan-Meier survival curves of the two subgroups of adult brainstem glioma. The 1-year actuarial survival rates for patients classified with low-grade and highgrade glioma were $89.9 \% \pm 0.06 \%$ and $20.2 \% \pm 0.09 \%$, respectively; a difference that was statistically significant $(\mathrm{p}<0.0001)$ (Figure 2).

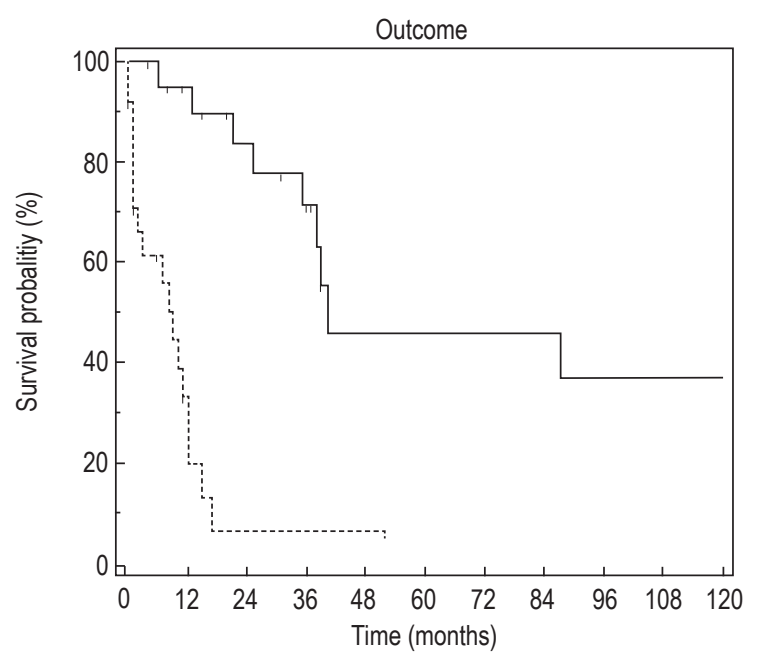

Figure 1 - Comparison of Kaplan-Meier survival curves of the two main subgroups of adult brainstem glioma. Continuous line low-grade glioma; dotted line, high-grade glioma (Logrank test $p<0.0001$ ). 


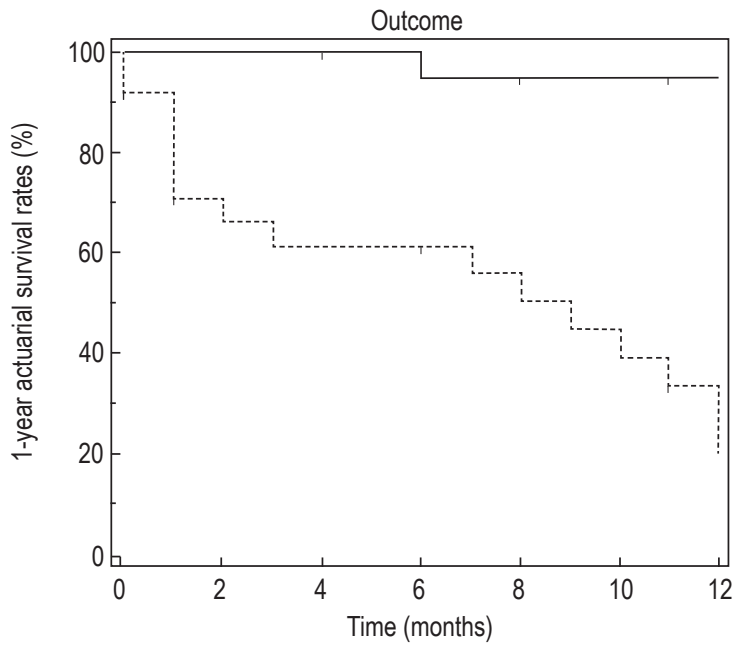

Figure 2-Kaplan-Meier curves for 1-year actuarial survival rates. Continuous line, low-grade glioma; dotted line, high-grade glioma (Logrank test $p<0.0001)$.

Other tumoral lesions were found in 19 cases including 9 metastasis, 7 primary brain lymphomas, 1 ganglioglioma, 1 ependymoma and 1 craniopharyngeoma. Non-tumoral lesions were diagnosed in 11 cases: 4 vascular lesions, 2 abscesses, 1 infarct and 4 acute inflammatory demyelinating diseases.

Fifty-five patients received conventional radiotherapy; 46 patients with low-grade or high-grade glioma and 9 with metastasis. Four patients were underwent radiosurgery: 3 with low-grade glioma (1pylocitic astrocytoma, 1 astrocytoma grade II and 1 oligodendroglioma) and 1 ependymoma.

Chemotherapy was administered to 23 patients:in all patients with primary lymphoma, 13 with glioma and 3 with metastasis. Surgical resection was realized in 4 patients as follows: 1 craniopharyngeoma, 1 pylocitic astrocytoma and in 2 which the biopsy did not result a diagnosis. Three patients with tumoral lesions were not treated because they presented minor symptoms and nonprogressive tumors during follow-up (1 ganglioglioma, 1 astrocytoma grade II and 1 pylocitic astrocytoma).

The overall morbidity rate associated with biopsy in present study was $10 \%$. Two patients developed third cranial nerve paresis, one presented exacerbation of a preoperative left facial paresis, two patients presented exacerbation of a preoperative hemiparesis and two patients developed deglutition impairment. One patient died of causes associated with the procedure.

Univariate analysis of the characteristics of the procedure (approach, technique utilized) revealed no statistically significance related to the success of the same: approach $(\mathrm{p}=0.51)$, technique used $(\mathrm{p}=0.81)$; nei- ther factor was related to mortality and morbidity rates: approach $(p=0.53)$ and technique used $(p=0.22)$.

\section{Discussion}

The management of brainstem mass lesions remains controversial; particularly when the lesion cannot be removed. ${ }^{2,7,8}$ One objection to performing a brainstem stereotactic biopsy procedure is that it may not be reliable, since the tumor may be heterogeneous.,14,19 Moreover, this heterogeneity often requires multiple sampling, which is potentially dangerous in the brainstem. ${ }^{14}$ In the current series, only one procedure-related death was reported and procedure-related morbidity was confined to eight patients. Morbidity associated with a brainstem biopsy in the recently reported literature ranges from 2.5 to $11 \%$; the results reported here are within this range. ${ }^{2,7,12.13 .16}$

Currently, a number of authors contend that obtaining histological diagnosis of brainstem tumors by a biopsy procedure is not required in most cases due to effectiveness of modern cerebral imaging modalities, especially MRI. ${ }^{2}$ However, for others, obtaining a stereotactic biopsy sample of brainstem mass lesions remains the best diagnostic procedure because a presumptive diagnosis based on MRI findings alone may lead to inaccurate diagnosis and, more importantly, erroneous treatment. ${ }^{3,16}$

The present study obtained a histological diagnosis in $96.3 \%$ of the cases. This diagnostic success rate is similar to the previously reported series, ranging from $87 \%$ to $100 \%$. $^{9}$ Only $62.5 \%$ of the patients had the diagnosis of high-grade or low-grade glioma.

Two patients with pylocitic astrocytoma were treated; one by surgical resection and one by chemotherapy and radiosurgery. In 19 cases the diagnosis was some other tumoral lesion, as follows: 7 primary brain lymphoma, 1 ganglioglioma and 1 craniopharyngeoma. In such cases the first-line of treatment is not the conventional radiotherapy. ${ }^{10,11,15}$ Moreover, in 11 patients the diagnosis was of non-tumoral lesion. However, in at least 22 cases $(28.7 \%)$ the biopsies had a direct impact on treatment.

It is highly probable that conventional fractionated radiotherapy will not remain the only efficient treatment in brainstem glioma in the next few decades. Indeed, radiosurgery and new chemo, gene or immunotherapies, separately or in combination, will certainly succeed in improving the outcome of these patients. ${ }^{5,20}$ These therapies will undoubtedly require tissue sampling for diagnostic confirmation and tumor grading, for mole- 
cular marker studies, or for immunological purposes prior to adopting target therapies. ${ }^{13}$

The present study demonstrated that survival was better in patients with low-grade glioma than highgrade glioma (Figures 1 and 2). Moreover, there is a wide spectrum of diverse histological type observed in these tumors. It has recently been suggested that tumor sampling may help in establishing the prognosis by using the biological and genetic characterization of the tumor. Several molecular markers have been identified in diffuse gliomas that provide diagnostic and prognostic information. In addition, some of these and other markers may predict the response of these gliomas to particular therapeutic approaches. ${ }^{6}$

\section{Conclusion}

Empirical treatment of adult brainstem lesions is not prudent because a wide spectrum of pathologies occur in this location. Stereotactic biopsy is a safe and effective method for determining histopathology.

As new treatment protocols continue to be developed, the use of a stereotactic biopsy to obtain a tissue samples aimed at specific tumor characterization of intrinsic brainstem lesions may become standard procedure.

\section{References}

1. Aker FV, Hakan T, Karadereler S, Erkan M. Accuracy and diagnostic yield of stereotactic biopsy in the diagnosis of brain masses: comparison of results of biopsy and resected surgical specimens. Neuropathology. 2005;25:207-13.

2. Albright AL, Packer RJ, Zimmerman R, Rorke LB, Boyett J, Hammond GD. Magnetic resonance scans should replace biopsies for the diagnosis of diffuse brainstem gliomas: a report from Children's Cancer Group. Neurosurgery. 1993;33:1026-30.

3. Coffey RJ, Lunsford LD. Stereotactic surgery for mass lesions of the midbrain and pons. Neurosurgery. 1985;17:12-8.

4. Gleason CA, Wise BL, Feinstein B. Stereotactic localizaion (with computerized tomographic scanning), biopsy, and radiofrequency treatment of deep brain lesions. Neurosurgery. 1978;2:217-22.

5. Hargrave D, Bartels U, Bouffet E. Diffuse brainstem glioma in children: critical review of clinical trials. Lancet Oncol. 2006;7:241-8

6. Jeuken JW, Van der Maazen RW, Wesseling P. Molecular diagnostics as a tool to personalize treatment in adult glioma patients. Technot Cancer Res Treat. 2006;5:215-29.
7. Kondziolka D, Lunsford LD. Results and expectations with image-integrated brainstem lesions. Surg Neurol. 1995;43:558-62.

8. Kratimenos GP, Thomas DGT. The role of image-directed biopsy in the diagnosis and management of brainstem lesions. Br J Neurosurg. 1993;7:155-64.

9. Massager N, David P, Goldman S, Pirotte B, Wikler D, Salmon I, et al. Combined magnetic resonance imaging and positron emission tomography - guided stereotactic biopsy in brainstem mass lesions: diagnostic yield in a series of 30 patients. J Neurosurg. 2000;93:951-7.

10. Minniti G, Esposito V, Amichetti M, Enrici RM. The role of fractionated radiotherapy and radiosurgery in the management of patients with craniopharyngioma. Neurosurg Rev. 2009; 23:145-9

11. Mpairamidis E, Alexiou GA, Stefanaki K, Sfakianos G, Prodromou N. Brainstem ganglioglioma. J Child Neurol. 2008;23:1481-3.

12. Pincus DW, Richter EO, Yachnis AT, Bennett J, Bhatti MT, Smith A. Brainstem stereotactic biopsy sampling in children. J Neurosurg (2 Suppl Pediatrics). 2006;104:108-14.

13. Pirotte BJ, Lubansu A, Massager N, Wikler D, Goldman S, Levivier M. Results of positron emission tomography guidance and reassessment of the utility of an indications for stereotactic biopsy in children with infiltrative brainstem tumors: J Neurosurg (5 Suppl Pediatrics). 2007;107:392-9.

14. Ranjan A, Rajshekhar V, Joseph T, Chandy MJ, Chandi SM. Nondiagnostic CT-guided stereotatic biopsies in a series 407 cases: influence of CT morphology and operator experience. J Neurosurg. 1993;79:839-44.

15. Reni M, Ferreri AJ. Therapeutic management of refractory or relapsed primary central nervous system lymphomas. Ann Hematol. 2001;3:113-7.

16. Roujeau T, Machado G, Garnett MR, Miquel C, Puget $\mathrm{S}$, Geoerger B, et al. Stereotactic biopsy of diffuse pontine lesions in children. J Neurosurg (Suppl Pediatrics). 2007;107:1-4

17. Selvapandian S, Rajshekhar V, Chandy MJ. Brainstem glioma: comparative study of clinico-radiological presentation, pathology and outcome in children and adults. Acta Neurochir (Wien). 1999;141:721-7.

18. Steck J, Friedaman WA. Stereotactic biopsy of brainstem mass lesions: Surg Neurol. 1995;43:563-8.

19. Willems JG, Alva-Willems JM. Accuracy of cytologic diagnosis of central nervous system neoplasms in stereotactic biopsies. Acta Cytol. 1984;28:243-9.

20. Yen CP, Sheehan J, Steiner M, Patterson G, Steiner L. Gamma knife surgery for focal brainstem gliomas. J Neurosurg. 2007:106:8-17.

Original recebido em abril de 2009

Aceito para publicação em setembro de 2009

Endereço para correspondência

Marcos Dellaretti

Rua Santa Helena, 68, apt. 400.

30220-240 - Belo Horizonte, $M G$

E-mail:mdellaretti@mac.com 